\title{
A família em disputa: o Supremo Tribunal Federal, a Frente Parlamentar Evangélica e o reconhecimento de uniões homoafetivas
}

\author{
Sandra Duarte de Souza \\ Tainah Biela Dias
}

\section{Resumo}

As disputas contemporâneas acerca da(s) família(s) têm mobilizado distintos setores da sociedade, seja pelo reconhecimento de outros arranjos familiares que não os convencionados pelo senso comum, seja pela defesa de um único padrão familiar, que evoca a existência de uma "família natural", diga-se, heterossexual, rejeitando quaisquer configurações familiares. Tais disputas estão presentes também no âmbito dos poderes da República. No presente artigo, trataremos especificamente do reconhecimento de uniões homoafetivas pelo Supremo Tribunal Federal e das reações de integrantes da Frente Parlamentar Evangélica a essa decisão, explicitando o caráter político-religioso desse debate.

Palavras-chave: Família. Uniões Homoafetivas. Judiciário. Parlamentares Evangélicos.

\section{The family in dispute: The Federal Supreme Court, the Evangelical Parliamentary Front and the recognition of homoaffective unions}

\begin{abstract}
Contemporary disputes about the family(ies) have mobilized distinct sectors, either by the recognition of other family arrangements other than those agreed by common sense, or by the defense of a single family pattern, which evokes the existence of a "natural family", say, heterosexual, rejecting any other family settings. Such disputes are also present within the scope of the powers of the Republic. In this article, we will deal specifically with the recognition of homoaffective unions by the Federal Supreme Court and the reactions of members of the Evangelical Parliamentary Front to this decision, making explicit the political and religious character of this debate.
\end{abstract}

Keywords: Family. Homoaffective unions. Judiciary. Evangelical Parliamentarians. 


\section{La familia en disputa: La Corte Suprema, el Frente Parlamentario Evangélico y el reconocimiento de Uniones homoafetivas}

\section{Resumen}

Las disputas contemporáneas acerca de la(s) familia(s) han movilizado a diferentes sectores de la sociedad, tanto por el reconocimiento de otros arreglos familiares no acordados por el sentido común, como por la defensa de un solo modelo familiar que evoca la existencia de una "familia natural", quiere decir, heterosexual, rechazando cualquier otra configuración familiar. Tales disputas están presentes también en el marco de los poderes de la República. En este artículo abordaremos específicamente el reconocimiento de uniones de personas del mismo sexo por la Corte Suprema y las reacciones de los miembros del Frente Parlamentario Evangélico a esta decisión, demostrando el carácter político-religioso de este debate.

Palabras clave: Familia. Uniones Homoafetivas. Judicial. Parlamentarios Evangélicos.

\section{Introdução}

"Toda sociedade procura acondicionar a forma da família a suas necessidades e fala-se em 'decadência' frequentemente para estigmatizar mudanças com as quais não concordamos” (PERROT, 1993, p. 75).

Uma instituição central nos debates que questionam as ideias de separação entre público e privado é a família. Ainda que costumeiramente associemos a família ao ambiente doméstico, entendido, por sua vez, como privado, suas diferentes configurações ao longo da História delineiam os contornos de aspectos fundamentais da vida social, que reverberam no espaço público.

O trabalho de Elizabeth Roudinesco, intitulado A Família em Desordem (2003), é imprescindível nesse debate, pois a autora discorre sobre transformações históricas ocorridas no seio da instituição familiar, decorrentes do controle religioso, do advento de novas tecnologias reprodutivas, das novas configurações de trabalho na sociedade moderna, entre outros. Porém, um fato destacado pela autora, claramente influenciada por sua inserção na psicanálise, é o fato de que a família é objeto de desejo. A despeito de discursos catastrofistas a respeito da destruição da família, como alguns dos que veremos neste artigo, a autora salienta que a família é, historicamente, "[...] reivindicada como único valor seguro ao qual ninguém quer renunciar. Ela é amada, sonhada e desejada por homens, mulheres e crianças de 
todas as idades, de todas as orientações sexuais e de todas as condições" (ROUDINESCO, 2003, p. 91).

Se, por um lado, a família, como instituição social, sobrevive historicamente, por outro, observamos o recrudescimento daquilo que chamamos de "defesa da família", defesa essa que tem se consolidado como uma das principais bandeiras políticas de segmentos conservadores nos últimos anos. Se podemos demarcar, no período recente de nossa história política, o momento em que esse argumento se tornou mais recorrente e ganhou força, destacamos o ano de 2009, com o lançamento do Plano Nacional de Direitos Humanos 3 (PNDH-3), seguido do pleito eleitoral do ano de 2010. Como destaca Sandra Duarte de Souza (2013), as eleições desse ano marcam um primeiro período de destaque da ação política dos evangélicos como grupo de pressão para a manutenção de uma moral sexual tradicional, pois são perceptíveis as formas pelas quais o sexo foi politicamente instrumentalizado e utilizado como moeda de troca que assegurou o apoio de grupos políticos e lideranças evangélicas aos candidatos que disputavam as eleições presidenciais, à época, Dilma Rousseff, pelo Partido dos Trabalhadores (PT), e José Serra, pelo Partido da Social Democracia Brasileira (PSDB).

A ação política e organizada de evangélicos, notadamente daqueles que já compunham ou viriam a compor, a partir do pleito de 2010, a chamada Frente Parlamentar Evangélica (FPE), e as palavras de ordem que caracterizam o discurso da "defesa da família", marcam uma reação de setores conservadores da sociedade brasileira às ampliações e à visibilidade das demandas das chamadas minorias sexuais, notadamente da população LGBTIQ. Nesse cenário, os embates e disputas pelo significado jurídico e político do conceito de família tornam-se explícitos, assim como, nos permitem perceber a fluidez e o caráter fictício das fronteiras que buscam demarcar a separação entre os espaços público e privado.

Com o intuito de adensar as discussões a respeito de público e privado e da hipótese de que a família é um locus do fazer político e, portanto, também pública, utilizaremos episódios recentes que pulularam no cenário político brasileiro. Referimos, aqui, especialmente, à decisão do Supremo Tribunal Federal (STF) que, no ano de 2011, reconheceu as uniões homoafetivas como entidades familiares, e as respostas de políticos religiosos a esse evento. 


\section{A família entre o público e o privado}

A dicotomia entre público e privado, a hierarquização dessas esferas e a definição do que é de uma esfera ou de outra têm ocupado importante lugar na reflexão científica, em especial na teoria política, cuja visão predominante tende a afirmar tal separação. Na definição dos lugares nos quais alocar sujeitos e instituições, definem-se também diferentes graus de importância de tais sujeitos e instituições; definem-se os sujeitos e os objetos de regulação. Não é sem razão que historicamente homens e mulheres são identificados como sendo de esferas distintas, cabendo a eles o público, e a elas o privado, sendo um considerado superior ao outro. É essa percepção que motiva teóricas feministas a questionarem a teoria política que tem reproduzido a visão predominante de gênero na sociedade, e a discutirem a explícita associação dos homens à esfera pública, particularmente à ordem política e econômica, e as mulheres à esfera privada, em especial ao âmbito doméstico e à família. Tal associação revela também diferentes valorações para tais esferas, colocando público e privado e, por conseguinte, homens e mulheres, em patamares distintos. Do público derivam outros adjetivos como racional, superior e forte. No caso do privado, as adjetivações são bem diferentes: emocional, inferior e fraco. A normalização e naturalização dessa dicotomia provoca o estranhamento de qualquer situação que leve ao transbordamento das fronteiras aparentemente bem definidas dessas esferas.

Carole Pateman (1993), Susan Okin (2008) e Hanna Pitkin (1981) questionam essa abordagem dicotômica e as limitações da teoria política que até os dias de hoje tendem a reforçar a separação e a hierarquização entre público e privado. Para essas autoras, existe uma interdependência entre essas esferas que não pode ser negligenciada pelas Ciências Políticas, e essa interdependência pode ser constatada no conhecimento/reconhecimento de que a vida privada não acontece isolada da vida pública e vice-versa. Para Okin, a afirmação de que "o pessoal é político" pelas estudiosas feministas, quer dizer que:

...o que acontece na vida pessoal, particularmente nas relações entre os sexos, não é imune em relação à dinâmica de poder, que tem tipicamente sido vista como a face distintiva do político. (...) Nem o domínio da vida doméstica, pessoal, nem aquele da vida não-doméstica, econômica e política, podem ser interpretados isolados um do outro (2008, p. 314).

A ideia do isolamento do privado, o esvaziamento político da vida doméstica e pessoal e a oposição e hierarquização das esferas pública e 
privada, são caros à produção e manutenção dessa dinâmica de poder referida por Okin. O domínio doméstico só pode ser compreendido em relação ao público, e este em relação àquele. Os contornos do doméstico, sua composição e as relações de poder que se tecem nesse âmbito são definidos por sistemas além do doméstico. A divisão sexual do trabalho doméstico é política; a organização, distribuição e o exercício do poder no âmbito doméstico são políticos; a definição dos sujeitos da família é política; a própria definição de família é política.

As configurações familiares que fogem àquela que se estabeleceu como paradigmática são objeto permanente de tensões, de desqualificação, de deslegitimação e de tentativas de regulação por parte das mais diversas instituições e sujeitos sociais. Como, portanto, negar o conteúdo político dessa instituição? Os esforços de parlamentares da Frente Parlamentar Evangélica, no sentido de estabelecer uma definição restrita para família, um singular que nega o plural contido nessas configurações, encontram suporte num contexto sócio-político-religioso que acolhe discursos que evocam uma suposta "luta em defesa da família tradicional", ou como querem alguns, "luta em defesa da família natural". A "família natural” supõe a composição homem, mulher, filhos e filhas. Outras configurações familiares são aceitáveis porque inevitáveis, desde que não fujam à norma heterossexual. Daí as disputas pelo significado de família mobilizarem setores diversos como políticos, juristas, religiosos, movimentos sociais etc.

\section{A família entre o Poder Legislativo e o Poder Judiciário: o reconhecimento das uniões homoafetivas como entidades familiares}

Os debates sobre o conceito de família no Brasil têm perpassado, inevitavelmente, iniciativas que almejam regulamentar jurídica e politicamente as uniões homoafetivas. É contrariamente a essas tentativas que se ergue a bandeira da "defesa da família", empunhada por parlamentares que compõem a Frente Parlamentar Evangélica no Congresso Nacional.

No âmbito do poder legislativo, a visibilidade das demandas pela regulamentação de uniões não heterossexuais teve início no ano de 1995 , com o Projeto de Lei (PL) 1151/95, de autoria da então deputada Marta Suplicy (PT-SP), que dispunha sobre a parceria civil registrada. Outras proposições, nesse sentido, como o PL 580/2007, de autoria do então deputado Clodovil Hernandes (PTC-SP) e o PL 5120/2013, de autoria dos/ 
as deputados/as Jean Wyllys (PSOL-RJ) e Érika Kokay (PT-DF), também versam sobre o reconhecimento jurídico de casamento e união estável entre pessoas do mesmo sexo e, hoje, tramitam apensados. Entretanto, a despeito das dificuldades encontradas no legislativo para a votação e aprovação de projetos de lei sobre direitos da população LGBTIQ, os maiores avanços recentes para a garantia de direitos dessa população vieram via judiciário.

No ano de 2011, foi reconhecida como entidade familiar a união entre pessoas do mesmo sexo pelo Supremo Tribunal Federal (STF) durante o julgamento da Ação Direta de Inconstitucionalidade (ADI) no 4.277 e da Arguição de Descumprimento de Preceito Fundamental (ADPF) nº. 132. As ações foram julgadas em conjunto, com a finalidade de conferir interpretação ancorada na Constituição Federal de 1988 e no Código Civil de 2002 à matéria.

Em sua fala, o relator da ADI n .4 .277 e da ADPF $n^{\circ} .132$, então Ministro, Carlos Ayres Britto, salientou estar ciente de que "nada incomoda mais as pessoas do que a preferência sexual alheia, quando tal preferência já não corresponde ao padrão social da heterossexualidade" (SUPREMO TRIBUNAL FEDERAL, 2011, p. 627, grifos no original). Britto enfatiza que sua argumentação vai ao encontro da defesa das liberdades individuais e contrariamente às formas de preconceito e discriminação contra pessoas LGBTIQ, embasando-se no artigo $5^{\circ}$. da Constituição Federal de 1988. ${ }^{1}$ Ao término de seu parecer, declara a necessidade de proteção e garantias jurídicas que abarquem as uniões homoafetivas que, em sua interpretação, devem ser reconhecidas como entidades familiares, visto que concebe "família como fato cultural e espiritual ao mesmo tempo (não necessariamente como fato biológico)" (SUPREMO TRIBUNAL FEDERAL, 2011, p. 644). O voto do ministro encerra seu parecer equiparando as uniões homoafetivas às afetivas, ressaltando não haver qualquer elemento "que impeça o reconhecimento da união contínua, pública e duradoura entre pessoas do mesmo sexo como "entidade familiar", entendida esta como sinônimo perfeito de "família". Reconhecimento que deve ser feito segundo as mesmas regras e com as mesmas conseqüências da união estável heteroafetiva" (SUPREMO TRIBUNAL FEDERAL, 2011, p. 656).

Após a apreciação do relator ministro Ayres Britto, os demais ministros declararam seus votos. Cabe aqui a menção de alguns deles para entendermos

\footnotetext{
O referido artigo se encontra no item Dos Direitos e Garantias Fundamentais e versa sobre os Direitos e Deveres Individuais e Coletivos, garantindo a igualdade de direitos e deveres entre cidadãos brasileiros e estrangeiros residentes no país, indistintamente.
} 
da melhor forma os argumentos jurídicos acionados na defesa das uniões homoafetivas como entidades familiares.

A arguição do ministro Luiz Fux explicita aquilo que, juridicamente, tem se entendido pelo conceito de família. Em seu voto o ministro afirma:

O que caracteriza, do ponto de vista ontológico, uma família? Sem dúvida, não são os laços sanguíneos, pois os cônjuges ou companheiros não os têm entre si e, mesmo sem filhos, podem ser uma família; entre pais e filhos adotivos, também não os haverá. De igual modo, a coabitação não será necessariamente um requisito. Uma família se desintegra se, por exemplo, um filho vai estudar no exterior? É claro que não. [...] O que faz uma família é, sobretudo, o amor - não a mera afeição entre os indivíduos, mas o verdadeiro amor familiar, que estabelece relações de afeto, assistência e suporte recíprocos entre os integrantes do grupo. O que faz uma família é a comunhão, a existência de um projeto coletivo, permanente e duradouro de vida em comum. O que faz uma família é identidade, a certeza de seus integrantes quanto à existência de um vínculo inquebrantável que os une e os identifica perante os outros e cada um deles perante a sociedade. Presentes esses três requisitos, tem-se uma família, incidindo, com isso, a respectiva proteção constitucional (SUPREMO TRIBUNAL FEDERAL, 2011, p. 670-671, grifos no original).

A argumentação do magistrado torna-se imprescindível, na medida em que o nosso objetivo é o de demonstrar como a família é um conceito em disputa no cenário político brasileiro. Sua fala baseia-se no amor e no afeto como componente que justifica o reconhecimento das uniões homoafetivas como entidades familiares, além de demonstrar as desigualdades inerentes ao seu não reconhecimento como famílias. O ministro ressalta, ainda, o papel do Supremo Tribunal Federal em garantir que o Estado atue de forma a proteger suas minorias. Em suas palavras:

Canetas de magistrados não são capazes de extinguir o preconceito, mas, num Estado Democrático de Direito, detêm o poder de determinar ao aparato estatal a atuação positiva na garantia da igualdade material entre os indivíduos e no combate ostensivo às discriminações odiosas. Esta corte pode, aqui e agora, firmar posição histórica e tornar público e cogente que o Estado não será indiferente à discriminação em virtude da orientação sexual de cada um; ao revés, será o primeiro e maior opositor do preconceito aos homossexuais em qualquer de suas formas (SUPREMO TRIBUNAL FEDERAL, 2011, p. 668). 
O ministro Luiz Fux se norteia, portanto, na necessidade de combate às discriminações e preconceitos advindos da orientação sexual dos sujeitos e do papel ativo do Supremo Tribunal Federal na defesa dos direitos de minorias.

$\mathrm{O}$ voto do ministro Gilmar Mendes segue a mesma linha argumentativa. Em sua extensa argumentação, discorre sobre a necessidade de reconhecer direitos de minorias como direitos fundamentais básicos. Segue um fragmento do seu parecer:

[...] não estamos a falar apenas da falta de uma disciplina legislativa que permita o desenvolvimento de uma dada política pública. Nós estamos a falar, realmente, do reconbecimento do direito de minorias, de direitos fundamentais básicos. E, nesse ponto, não se trata de ativismo judicial, mas de cumprimento da própria essência da jurisdição constitucional (SUPREMO TRIBUNAL FEDERAL, 2011, p. 778, grifos no original).

Além do argumento da defesa dos direitos de minorias que sofrem com preconceito, discriminação e com o vazio jurídico no reconhecimento de suas uniões, um argumento recorrente nos votos de ministros do Supremo Tribunal Federal foi o da defesa da dignidade da pessoa humana, assim como, na defesa da liberdade, da igualdade e da intimidade. Esse é um dos focos da argumentação do ministro Ricardo Lewandowski, quando afirma:

[...] penso que se está diante de outra forma de entidade familiar [...] não prevista no rol encartado no art. 226 da Carta Magna, a qual pode ser deduzida a partir de uma leitura sistemática do texto constitucional e, sobretudo, diante da necessidade de dar-se concreção aos princípios da dignidade da pessoa humana, da igualdade, da liberdade, da preservação da intimidade e da não-discriminação por orientação sexual aplicáveis às situações sob análise (SUPREMO TRIBUNAL FEDERAL, 2011, p. 713).

Sob o princípio da dignidade da pessoa humana, os/as ministros/as argumentam não haver qualquer impedimento jurídico ao reconhecimento das uniões homoafetivas como entidades familiares. Esse mesmo argumento é reforçado na fala do ministro Joaquim Barbosa, quando diz que "[...] o reconhecimento dos direitos oriundos de uniões homoafetivas encontra fundamento em todos os dispositivos constitucionais que estabelecem a proteção dos direitos fundamentais, no princípio da dignidade da pessoa humana, no princípio da igualdade e da não-discriminação" (SUPREMO TRIBUNAL FEDERAL, 2011, p. 726-727). 
Por fim, a argumentação do ministro Marco Aurélio assevera a necessidade do reconhecimento das uniões homoafetivas como famílias, pois considera que a garantia de direitos patrimoniais somente é insuficiente. Em suas palavras:

[...] se duas pessoas de igual sexo se unem para a vida afetiva comum, o ato não pode ser lançado a categoria jurídica imprópria. A tutela da situação patrimonial é insuficiente. Impõe-se a proteção jurídica integral, qual seja, o reconhecimento do regime familiar. Caso contrário, [...] estar-se-á a transmitir a mensagem de que o afeto entre elas é reprovável e não merece o respeito da sociedade, tampouco a tutela do Estado, o que viola a dignidade dessas pessoas, que apenas buscam o amor, a felicidade, a realização (SUPREMO TRIBUNAL FEDERAL, 2011, p. 817).

Aqui, percebemos que a argumentação do ministro perpassa questões relativas à legitimidade das uniões homoafetivas, que permaneceriam questionadas caso não se decidisse reconhecê-las como entidades familiares. O não reconhecimento fortaleceria, portanto, a ideia de que famílias formadas por pessoas LGBTIQ não são, verdadeiramente, famílias, por não se construírem por meio de uma relação heterossexual.

A decisão do STF em reconhecer as uniões homoafetivas se tornou um marco na ampliação dos direitos sexuais e promoveu agitações nos debates a respeito do conceito de família no Brasil. As principais reações a essa decisão vieram de setores religiosos conservadores da sociedade brasileira, sobretudo católicos e evangélicos, e tomaram conta do Congresso Nacional.

No Diário da Câmara dos Deputados, é possível mapear diversos discursos proferidos por parlamentares que compõem a Frente Parlamentar Evangélica a respeito da decisão tomada pelo STF. Iniciamos com a fala do então deputado João Campos (PSDB-GO), ${ }^{2}$ à época presidente da Frente. ${ }^{3}$ Em sua arguição, o parlamentar afirma:

O Relator do processo no Supremo [Tribunal Federal], Ministro Ayres Britto, buscou um dicionário não sei onde que já começa a mudar até o conceito de casal. O conceito agora é de dupla: duas pessoas que se amam é casal,

2 João Campos é Pastor Auxiliar da Igreja Assembleia de Deus de Vila Nova (GO) e delegado.

3 Os partidos políticos a que pertencem os integrantes da Frente Parlamentar Evangélica podem ter sofrido alterações ao longo dos anos. Utilizaremos, aqui, a sigla do partido ao qual o parlamentar pertencia à época de sua fala na Câmara dos Deputados. 
independentemente do sexo, e daí por diante. Um absurdo! Começa a invocar princípios para dizer que o Constituinte, ao definir o que é união estável, não proibiu que outro tipo de união fosse também considerada como união estável. Isso é um perigo para a democracia, um perigo para o Brasil e um desrespeito a este Parlamento! (BRASIL, 2011a, p. 21.887).

Na fala do supracitado deputado, observamos com clareza sua preocupação com as possíveis mudanças nos conceitos de casal e união estável, que reverberam fortemente naquilo que também se entende por "defesa da família natural" ou "defesa da família tradicional". Essa fala é adensada, ainda, por discursos proferidos por outros parlamentares também evangélicos, como é o caso de Ronaldo Fonseca (PROS-DF). ${ }^{4}$ Demonstrando sua indignação frente à decisão do Supremo Tribunal Federal, o então deputado federal, declarou: "[...] acabou de falecer o conceito de família natural neste País [...] diante desse falecimento, peço a V.Exa., Sr. Presidente, e aos Deputados 1 minuto de silêncio em homenagem à morte antecipada do conceito de família natural" (BRASIL, 2011b, p. 22.356).

O deputado federal Ronaldo Nogueira também se manifestou a respeito, argumentando que a sociedade brasileira teria sido construída por pilares cristãos que sustentam aquilo que se entende por "família":

O povo brasileiro foi formado e tem seus valores fundamentados em princípios cristãos, princípios que pregam a família como célula mater da sociedade. Como se forma uma família? Pela união civil de um homem e uma mulher que geram filhos. Esse princípio não pode ser alterado. Não há lei ou interpretação humana que possa mudar esse conceito, que possa alterar esse valor (BRASIL, 2011c, p. 23.694).

Nogueira acrescenta, ainda, que a decisão do Supremo Tribunal Federal, favorável ao reconhecimento das uniões homoafetivas como entidades familiares, é contrária aos propósitos divinos, afirmando que "não podemos desconhecer que há práticas que confrontam a Sua santidade. E o Estado não pode interferir nessas práticas, tornando-as normais e legítimas" (BRASIL, 2011c, p. 23.649).

4 Ronaldo Fonseca deixou o cargo de deputado federal em maio de 2018 para assumir o cargo de Ministro Chefe da Secretaria Geral da Presidência do Brasil do governo Michel Temer. 
Ora, observando os discursos já citados, podemos perceber em quais argumentos se baseia a "defesa da família", uma das principais bandeiras da Frente Parlamentar Evangélica no Congresso Nacional. Além de discursos de parlamentares, consideramos que uma das reações de maior destaque à decisão do Supremo Tribunal Federal é o chamado Estatuto da Família, inscrito sob o PL 6.583/2013, de autoria do deputado federal e membro da Frente Parlamentar Evangélica, Anderson Ferreira (PR-PE). ${ }^{5} \mathrm{O}$ Estatuto dispõe, entre outras coisas, a respeito daquilo que seria o elemento definidor do conceito de família, dos direitos e garantias que devem ser concedidos a essa instituição social por parte do Estado brasileiro e sobre políticas públicas voltadas à segurança e bem-estar da família no que se refere à educação, saúde, violência doméstica, entre outros. Nosso interesse é, sobretudo, naquilo que concerne à definição do conceito de família, que conta com destaque em negrito no artigo $2^{\circ}$. do PL e que é constantemente reforçado por membros da FPE:

Artigo $2^{\circ}$. Para os fins desta Lei, define-se entidade familiar como o núcleo social formado a partir da união entre um homem e uma mulher, por meio de casamento ou união estável, ou ainda por comunidade formada por qualquer dos pais e seus descendentes (BRASIL, 2013, s/n).

Um destaque como esse não tem caráter inofensivo. Esse, aparentemente, simples detalhe em um documento que versa sobre demais assuntos é, em nossa percepção, uma clara tentativa de legitimar jurídica e politicamente, determinada configuração de família. Evidentemente, algo só pode ser estabelecido como legítimo quando contrastado com aquilo que é entendido como sua oposição, ou seja, o ilegítimo.

Se pensamos a família como submersa no limiar da separação entre aquilo que é privado e aquilo que é público, vemos, claramente, em proposições como o Estatuto da Família, a instrumentalização política da família para corroborar sistemas de exclusão, preconceito e discriminação que se inscrevem no seio de uma sociedade que, de forma hegemônica, compartilha de valores misóginos e homofóbicos. Apontar, de forma implícita, a existência de configurações familiares ilegítimas, faz parte da tentativa de estabelecer (ou perpetuar) a existência de cidadãos de segunda categoria. No

Anderson Ferreira é membro da Assembleia de Deus e filho do pastor e político Manoel Ferreira, presidente vitalício da Convenção Nacional das Assembleias de Deus no Brasil - CONAMAD. 
caso específico do debate sobre o conceito de família, essa segunda categoria tem relação direta com a não conformidade àquilo que Judith Butler (2015) denomina matriz heterossexual alimentada por discursos de verdade sobre o sexo. Em suas palavras:

A noção de que pode haver uma "verdade" sobre o sexo [...] é produzida precisamente pelas práticas reguladoras que geram identidades coerentes por via de uma matriz de normas de gênero correntes. A heterossexualização do desejo requer e institui a produção de oposições discriminadas e assimétricas entre "feminino" e "masculino", em que esses são entendidos como atributos expressivos de "macho" e "fêmea". A matriz cultural por intermédio da qual a identidade de gênero se torna inteligível exige que certos tipos de "identidade" não possam "existir" - isto é, aquelas em que o gênero não decorre do sexo e aquelas em que as práticas do desejo não "decorrem" nem do "sexo" nem do "gênero". Neste contexto, "decorrer" seria uma relação política de direito instituído pelas leis culturais que estabelecem e regulam a forma e o significado da sexualidade. Ora, do ponto de vista deste campo, certos tipos de "identidade de gênero" parecem ser meras falhas do desenvolvimento ou impossibilidades lógicas, precisamente porque não se conformam às normas da inteligibilidade cultural (BUTLER, 2014, p. 44).

Apoiando-nos nas discussões de Judith Butler, que, por sua vez, tem como base as análises foucaultianas acerca dos discursos de verdade (FOUCAULT, 1999, 2015), é possível perceber que os discursos de verdade sobre o sexo, que pressupõem a matriz heterossexual como única possibilidade culturalmente inteligível, estão concatenados à defesa de uma configuração única de família como legítima, produzindo, assim, um discurso de verdade sobre a família, ${ }^{6}$ amplamente defendido e reafirmado pelos

6 Não cabe nos propósitos deste artigo realizar uma análise esmiuçada dessa noção de discursos de verdade no contexto dos debates sobre o conceito de família, mas, para que o/a leitor/a se situe nesta discussão, cabe salientar que, na concepção do filósofo Michel Foucault, “[...] a verdade não existe fora do poder ou sem poder [...] A verdade é deste mundo; ela é produzida nele graças a múltiplas coerções e nele produz efeitos regulamentados de poder. Cada sociedade tem seu regime de verdade, sua "política geral" de verdade: isto é, os tipos de discursos que ela acolhe e faz funcionar como verdadeiros; os mecanismos e as instâncias que permitem distinguir os enunciados verdadeiros dos falsos, a maneira como se sanciona uns e outros; as técnicas e os procedimentos que são valorizados para a obtenção da verdade; o estatuto daqueles que têm o encargo de dizer o que funciona como verdadeiro" (FOUCAULT, 2015, p. 51-52). Se o/a leitor/a deseja análise pormenorizada a respeito das articulações entre as concepções foucaultianas de verdade e o discurso sobre a família, ver: DIAS, Tainah Biela (2017). 
parlamentares que compõem a Frente Parlamentar Evangélica (FPE) e reativo aos avanços nos direitos civis da população LGBTIQ. ${ }^{7}$

\section{Família e manutenção da ordem social: sobre os significados políticos da "família"}

As disputas envolvendo o reconhecimento das uniões homoafetivas como entidades familiares no poder legislativo e judiciário brasileiros nos levam a refletir acerca dos significados da família como instituição social. Por que a disputa por seu significado é importante? Quais suas implicações para a manutenção ou transformação de determinada ordem simbólica? Quais efeitos práticos e concretos essa ordem simbólica faz reverberar na realidade social e política? Todos esses questionamentos reforçam aquilo que já vem sendo afirmado no decorrer deste artigo: a família, a despeito do fato de ser entendida como componente da esfera do privado e da vida doméstica, é uma instituição política que afeta diretamente as formas pelas quais as relações sociais se fazem perceber no espaço público.

Flávia Biroli nos auxilia na compreensão dos significados políticos da família. Dissertando especificamente a respeito da importância da família como instituição social que determina as formas como se constroem as relações de gênero ao longo da História, a autora ressalta:

A família se define em um conjunto de normas, práticas e valores que têm seu lugar, seu tempo e uma história. É uma construção social, que vivenciamos. As normas e ações que se definem no âmbito do Estado, as relações de produção e as formas de remuneração e controle do trabalho, o âmbito da sexualidade e afetos, as representações dos papéis sociais de mulheres e homens, da infância e das relações entre adultos e crianças, assim como a delimitação do que é pessoal e privado por práticas cotidianas, discursos e normas jurídicas, incidem sobre as relações na vida doméstica e dão forma ao que reconhecemos como família (BIROLI, 2014, p. 7).

A família é uma construção social, que se transforma historicamente a depender do contexto social, histórico e cultural em que está inserida. Como instituição social, a família é politicamente instrumentalizada para regular as relações sociais entre os sexos, papéis sociais de homens e mulheres na sociedade e a sexualidade destes.

Para ter acesso a discursos proferidos por parlamentares evangélicos na Câmara dos Deputados, assim como outras proposições legislativas desse grupo referentes à família, ver: DIAS, Tainah Biela (2017). 
Ora, utilizando dessas reflexões para pensar o Estatuto da Família como tentativa de institucionalização jurídico-política de uma verdade sobre a família, sobretudo considerando que essa proposição surge a partir da bandeira defendida por uma bancada que se autodeclara religiosa, vemos claramente as implicações políticas dessa defesa. Insistir na existência de uma família legítima, é, ao mesmo tempo, legitimar papéis de gênero de homens e mulheres que correspondem ao ideal dessa família, assim como legitimar expressões da sexualidade e de identidade de gênero que, necessariamente, a formam. Essa defesa fundamenta-se em determinada moral sexual religiosa que, como salienta Tainah Biela Dias, busca instituir uma ideia ontológica de família. Nas palavras da autora:

Apostando numa família ontológica, na "obviedade" da família heterossexual como única correta por atender aos propósitos divinos da procriação e da perpetuação da espécie, tais discursos negligenciam, de forma propositada, todo e qualquer componente histórico que revele as transformações sofridas daquilo que conhecemos como família. Desta forma, a invocação de uma ontologia da família esconde registros históricos de uma pluralidade inegável de arranjos familiares nas sociedades não Ocidentais e não cristãs. E mesmo ainda esconde que nas sociedades Ocidentais e cristãs em sua maioria, as configurações familiares já tiveram e ainda têm diferentes composições em determinadas épocas e atenderam a diferentes propósitos, sejam estes sociais, políticos ou econômicos (DIAS, 2017a, p. 93-94).

Essa ontologia da família traz consigo implicações práticas que moldam o cotidiano das relações de gênero e sexualidade. A ideia de família, como proposta pelos parlamentares que compõem a FPE, carrega consigo a tentativa de perpetuação de papéis de gênero social, cultural e religiosamente atribuídos a homens e mulheres (DIAS, 2017b). Nesse sentido, LGBTIQ fobia e sexismo se entrecruzam e reforçam mutuamente, pois reforçam uma ideia de família que se baseia na necessidade de um homem que cumpra as atribuições a ele designadas (provisão financeira, chefia do lar, dominação sobre sua esposa) e de uma mulher que exerça a maternidade como vocação e que cuide dos afazeres domésticos. Por sua vez, esses papéis sociais generificados produzem efeitos que extrapolam a vida doméstica e alcançam o espaço público. Como afirma Flávia Biroli:

Moral sexual e direito de família estiveram, também, permanentemente relacionados. A ausência do direito ao divórcio, e as formas assumidas pelas 
leis quando esse direito foi conquistado, assim como a aceitação ao longo dos séculos, do direito do marido de punir sua esposa por desvios, inclusive por meio de castigos físicos, são exemplos importantes de como a esfera privada das relações familiares se organiza em hierarquias, que ganham legitimidade no mundo público e são peças fundamentais na sustentação de uma ordem social que excede a vida doméstica (BIROLI, 2014, p. 22-23).

É partindo do entendimento de que a família é uma instituição social capaz de legitimar estruturas de poder e dominação, que vão além do espaço doméstico, que a defesa da família tem sido uma das principais bandeiras da Frente Parlamentar Evangélica (FPE). Os avanços recentes da cidadania LGBTIQ, assim como reivindicações dos direitos das mulheres por parte dos movimentos feministas, são tão incômodos e tratados como "ameaças" porque colocam em xeque verdades absolutas sobre categorias que simbolicamente legitimam hierarquias e desigualdades, como os papéis de gênero, a sexualidade e instituições sociais como o casamento e a família, entre outras.

Foi o reconhecimento das uniões homoafetivas como entidades familiares, nesse sentido, que se configurou como o estopim da consolidação do inimigo a ser combatido em nome da família tradicional que, por sua vez, é elemento constitutivo e fundamental para a manutenção de determinada ordem simbólica. Essa é a função política da família. É por meio dela, como primeira instituição responsável pela socialização, que se faz garantir a reprodução de valores que garantam a imutabilidade do status quo. Como afirma Valéria Busin:

A família é, para diversas tradições religiosas, um locus privilegiado de transmissão e/ou socialização de valores e princípios religiosos. Como as religiões não dispõem de mecanismos coercitivos, elas instituem uma aliança com a família - fazendo a apologia desta -, que inculca em seus membros, especialmente nos das gerações sucessoras, os valores morais defendidos pelas religiões (BUSIN, 2011, p. 115).

É justamente por conta da importância da família na transmissão de valores (inclusos aqui os valores religiosos) que as disputas por seu significado têm sido visíveis no cenário político brasileiro. Essa exasperada defesa da família, entendida como legítima apenas em sua configuração heterossexual, cisgênera e monogâmica, vai na contramão da diversidade e pluralidade 
característicos de Estados democráticos. É nessa toada que se dão as reflexões da jurista e especialista em direito de família, Maria Berenice Dias. De acordo com a autora:

É necessário ter uma visão pluralista da família, que abrigue os mais diversos arranjos familiares, devendo-se buscar o elemento que permite enlaçar no conceito de entidade familiar todos os relacionamentos que têm origem em um elo de afetividade, independentemente de sua conformação. Esse referencial só pode ser identificado no vínculo que une seus integrantes. É o envolvimento emocional que leva a subtrair um relacionamento do âmbito do direito obrigacional - cujo núcleo é a vontade - para inseri-lo no direito das famílias, que tem como elemento estruturante o sentimento do amor que funde as almas e confunde patrimônios, gera responsabilidades e comprometimentos mútuos. Esse é o divisor entre o direito obrigacional e o familiar: os negócios têm por substrato exclusivamente a vontade, enquanto o traço diferenciador do direito da família é o afeto. A família é um grupo social fundado essencialmente nos laços de afetividade após o desaparecimento da família patriarcal, que desempenhava funções procriativas, econômicas, religiosas e políticas (DIAS, 2015, p. 133).

O argumento da jurista Maria Berenice Dias se une aos argumentos, já explorados, dos/as ministros/as do Supremo Tribunal Federal. Todos versam sobre a necessidade do reconhecimento de que a família é uma instituição plural, que possui diversas configurações que não devem ser sobrepostas em hierarquias fundamentadas em questões de orientação sexual e identidade de gênero. Entretanto, a percepção da pluralidade de configurações familiares, a defesa e o reconhecimento de sua legitimidade como instituições são entendidos como ameaça para aqueles que defendem uma configuração única de família como legítima.

\section{Considerações finais}

O reconhecimento de uniões homoafetivas pelo Supremo Tribunal Federal e as reações de integrantes da Frente Parlamentar Evangélica a essa decisão explicitaram o caráter político-religioso dessa instituição, que não aceita se conformar a um modelo único: a família. A pluralidade de configurações familiares desafia a monotonia do singular "família", e movimenta sujeitos e instituições a repensarem seus não tão sólidos argumentos em defesa de uma suposta "família natural". A percepção de que novas configurações familiares são ameaçadoras não à família como instituição 
social, mas sim à posição privilegiada da heterossexualidade cisgênera e dos valores religiosos que a legitimam como consequência de uma sexualidade correta, nos permite entender o porquê de disputas políticas, sociais e de ordem simbólica que objetivam o monopólio de seus significados, de seu conceito e de sua definição no campo político brasileiro.

Ainda hoje os modos de significação e regulação social da sexualidade mobilizam diferentes forças sociopolíticas, e isso se manifestou no debate sobre o reconhecimento de uniões homoafetivas no Brasil. A reação de parlamentares da FPE no esforço de afirmar e validar um único modelo de família e, por conseguinte, validar o sexo correto e o objetivo correto do sexo (SOUZA, 2017, p. 56), expressa esse desejo de poder sobre a(s) família(s).

As chamadas novas famílias abrem brechas para o questionamento da própria força das instituições religiosas como produtoras de uma moral sexual que exerce efeitos de regulação. Ter o afeto como base para uma nova definição jurídica e política do conceito de família elimina seu caráter generificado e corrobora com a afirmação das liberdades individuais, sobretudo aquelas que se referem ao corpo e à sexualidade.

\section{Referências}

BIROLI, Flávia. Família: novos conceitos. São Paulo: Fundação Perseu Abramo, 2014.

BRASIL. Congresso Nacional. Câmara dos Deputados. Diário da Câmara dos Deputados. Brasília, 2011, ano LXVI, n. 75, 2011a. Disponível em: http://imagem.camara.gov.br/ Imagem/d/pdf/DCD06MAI2011.pdf\#page=. Acesso em: 12 nov. 2018.

BRASIL. Congresso Nacional. Câmara dos Deputados. Diário da Câmara dos Deputados. Brasília, 2011, ano LXVI, n. 76, 2011b. Disponível em: http://imagem.camara.gov.br/ Imagem/d/pdf/DCD06MAI2011.pdf\#page=. Acesso em: 12 nov. 2018.

BRASIL. Congresso Nacional. Câmara dos Deputados. Diário da Câmara dos Deputados. Brasília, 2011, ano LXVI, n. 80, 2011c. Disponível em: http://imagem.camara.gov.br/ Imagem/d/pdf/DCD06MAI2011.pdf\#page=. Acesso em: 12 nov. 2018.

BRASIL. Congresso Nacional. Projeto de Lei PL 6583/2013. Dispõe sobre o Estatuto da Família e dá outras providências. Disponível em: http://www.camara.gov.br/proposicoesWeb/ fichadetramitacao?idProposicao=597005. Acesso em: 21 out. 2018.

BRASIL. Constituição (1988). Constituição da República Federativa do Brasil. Disponível em: http://www.planalto.gov.br/ccivil_03/constituicao/constituicao.htm. Acesso em: 21 out. 2018.

BUSIN, Valéria Melki. Religião, sexualidades e gênero. Rever - Revista de Estudos de Religião, ano 11, n. 1, jan./jun. 2011, p. 105-124.

BUTLER, Judith. Problemas de gênero: feminismo e subversão da identidade. Rio de Janeiro: Civilização Brasileira, 2015. 
DIAS, Maria Berenice. Manual de direito das famílias. São Paulo: Editora Revista dos Tribunais, 2015.

DIAS, Tainah Biela. Sobre Religião, Estado Laico e Cidadania LGBT+: a Frente Parlamentar Evangélica e a defesa da verdade sobre a família, 2017, 151p. Dissertação de Mestrado (Ciências da Religião). Universidade Metodista de São Paulo, São Bernardo do Campo, 2017a.

DIAS, Tainah Biela. A Defesa da Família Tradicional e a Perpetuação dos Papéis de Gênero Naturalizados. Mandrágora, v. 23, n. 1, jan./jun. 2017b, p. 49-70.

FOUCAULT, Michel. A ordem do discurso. São Paulo: Loyola, 1999.

FOUCAULT, Michel. Microfísica do poder. São Paulo: Paz e Terra, 2015.

OKIN, Susan Moller. Gênero, o público e o privado. Revista Estudos Feministas. Florianópolis, v. 16, n. 2, p. 305-332, 2008.

PATEMAN, Carole. Garantir a cidadania das mulheres: a indiferença e outros obstáculos. Revista Crítica de Ciências Sociais. Coimbra, n. 89, p. 29-40, jun. 2010.

PATEMAN, Carole. O Contrato Sexual. São Paulo: Paz e Terra, 1993.

PERROT, Michelle. O nó e o ninho. In: Veja 25 anos - Reflexões para o futuro. São Paulo: Abril, 1993, p. 75-82.

PITKIN, Hanna F. Justice: on relating private and public. Political Theory, v. 9, n. 3, p. 327-352, ago. 1981.

ROUDINESCO, Elisabeth. A família em desordem. Rio de Janeiro: Zahar, 2003.

SOUZA, Sandra Duarte. Política religiosa e religião política: os evangélicos e o uso político do sexo. Estudos de Religião, v. 27, n. 1, 2013, p. 177-201.

SOUZA, Sandra Duarte de. Entre o diverso e o controverso: direitos LGBT e atuação de deputados e deputadas federais das bancadas católica e evangélica. In: FERRARI, Anderson e CASTRO, Roney Polato (orgs.). Diversidades sexuais e de gêneros: desafios e potencialidades de um campo de pesquisa e conhecimento. Campinas: Pontes, 2017, p. 51-73.

Supremo Tribunal Federal. Arguição de Descumprimento de Preceito Fundamental 132 Rio de Janeiro. Disponível em: <http://redir.stf.jus.br/paginadorpub/ paginador.jsp?docTP=AC\&docID $=628633>$. Acesso em: 7 nov. 2011.

SUPREMO TRIBUNAL FEDERAL. Ação Direta de Inconstitucionalidade 4.277 Distrito Federal. 2011. Disponível em: <http://redir.stf.jus.br/paginadorpub/paginador. jsp?docTP=AC\&docID=628635>. Acesso em: 7 nov. 2016.

Submetido em: 13-11-2018

Aceito em:25-11-2018 